\title{
Skarn-scheelite ores beneficiation stimulation using ultrasonic treatment
}

\author{
Elena Shepeta ${ }^{1 *}$ and Luiza Samatova ${ }^{1}$ \\ ${ }^{1}$ Mining Institute of Far eastern branch of Russian Academy of Sciences Khabarovsk, Russia
}

\begin{abstract}
The impact of acoustic vibrations on physical and chemical properties of circulating water, heterogenic systems of pulps of sulphide and scheelite cycles flotations, collectors (IMA-I413p (potassium butyl xanthate), sodium oleate of commercial acid B-115) have been studied on skarn scheelite-quartz-sulphide ore of Vostok-2 deposit. Ultrasonic treatment has been performed using UZDN-2T apparatus. Working frequency $22 \mathrm{kHz}$, absorbed acoustic power average for radiator Pak $=46$ $\mathrm{W}$, sound intensity average $\mathrm{I}_{\mathrm{us}}=1 \mathrm{~W} / \mathrm{cm}^{2}\left(\right.$ rated $\left.\mathrm{I}_{\mathrm{us}}=2-3 \mathrm{~W} / \mathrm{cm}^{2}\right)$. During all experiments, ultrasonic treatment time was constant -5 minutes, insonation solutions volume $-250-100 \mathrm{ml}$, solutions heating temperature in the course of insonation $-25-35^{\circ} \mathrm{C}$. The flotation tests patterns, reagent scheme are approximate to process regulation of Primorskaia oreprocessing plant processing ores of given deposit. Utmost increment of extraction in case of collctors ultrasonic treatment has been reached on dialkyldithiophosphate (IMA-I413p), the increment of extraction of chalcopyrite into bulk sulphide concentrate $0.98 \%$. The best results of testing of ultrasonic treatment impact on scheelite ores beneficiation have been obtained in case of ultrasound impact on circulating water. In consequence of stimulation of precious minerals flotation increment of extraction of chalcopyrite into copper concentrate by $1.4 \%$ and scheelite into bulk rough concentrate by $2.5 \%$ has been obtained.
\end{abstract}

\section{Introduction}

Despite the fact that ultrasonic treatment of ores and metals spread already in 60-s of the previous century, up to this day it is considered new and advanced method for future development of mineral deposits beneficiation [1-4]. Such state of things is conditioned by the absence of industrial designs of inexpensive high-performance reliable ultrasonic units. Currently, prevailing are ultrasonic baths for items treatment and the acceleration of physical and chemical processes in liquids. Main manufacturers of laboratory ultrasonic units, in domestic industry, are "Aleksandra-Plius", LLC, units have been supplied to Moscow Institute of Steel and Alloys, "Central research geological-prospecting institute of non-ferrous and noble metals" Federal State Unitary Enterprise, "GVINTSVETMET" Federal State Unitary Enterprise, "Uralmekhanobr" OJSC and etc [5]. Industrial jump in modern technologies and equipment development allows suggesting intensive development

\footnotetext{
*Corresponding author: Elenashepeta56@mail.ru,
} 
as well as in the field of creation of industrial ultrasonic units what actualizes the researches in the field of ore beneficiation using ultrasonic treatment [6].

\section{Experimental technique}

Testing of ultrasonic treatment impact on efficiency of beneficiation of scheelite and chalcopyrite on ores of Vostok-2 deposit, in given research, was conducted on sample weights of $125 \mathrm{~g}$. Size degradation was carried out in "Pulverisette-5" planetary mill: solid mineral mass/ball load/liquid substance ratio - 1:3.7:0.8, ball diameter $-20 \mathrm{~mm}$, time of size degradation -7 minutes, content of flotation class in flotation feed $-73 \%$, distribution of $\mathrm{WO}_{3}-80.6 \%$ (including sludge $16.5 \%$ ), $\mathrm{Cu}-84,7 \%$ which correlates to data of size degradation of one kilogram of sample weights in a ball mill.

Ultrasonic treatment of skarn scheelite-sulphide ore was performed using UZDN-2T apparatus, the radiator of which allows ultrasonic treatment of small quantities of mineral media (to $350 \mathrm{ml}$ ). Working frequency $22 \mathrm{kHz}$. Absorbed acoustic power average for radiator Pak $=46 \mathrm{~W}$, sound intensity average $\mathrm{I}_{\mathrm{us}}=1 \mathrm{~W} / \mathrm{cm}^{2}$ (data obtained based upon performed researches by mineral deposits beneficiation laboratory). Rated approximate values for the device intensity $-\mathrm{I}_{\mathrm{us}}=2-3 \mathrm{~W} / \mathrm{cm}^{2}$.

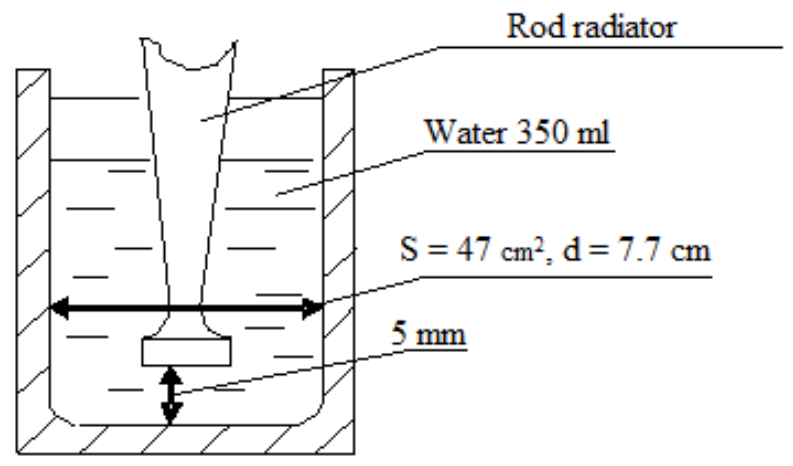

Fig. 1. Exponential rod concentrator (design A)

Exponential rod concentrator with a disc on the end is designed for treatment of media in laboratory breakers with the maximum capacity of $400 \mathrm{ml}$, ultrasonic vibrations are coupled in the breaker from the top.

During all experiments, ultrasonic treatment time was constant -5 minutes, insonation solutions volume $-250-100 \mathrm{ml}$, solutions heating temperature in the course of insonation $-25-35^{\circ} \mathrm{C}$.

Typical pattern of copper-sulphide and scheelite cycles. Main reagent of sulphide cycle: sodium silicate, aeroflot IMA-I413p, pine oil, activated carbon, trisodium phosphate; of scheelite cycle: sodium carbonate, sodium silicate, sodium oleate of commercial acid B115. The consumption of reagents for bulk cycles were constant in all experiments and corresponding to reagent scheme of Primorskaia ore-processing plant. During finishing cycles, the consumption of reagents was being defined by the quality of rough concentrate.

\section{Results and discussion}

In case of ore beneficiation, acoustic vibrations obtained most wide spread during treatment of flotation reagents (apolar oils, fatty acids, amines and etc.) which are hardly soluble in water. In production, ultrasound emulsification of oleic acid, tall oil, kerosene, aeroflot, naphthenic acids which allows stimulating the process of reagents dilution in the volume of 
pulps in case of decrease in reagents consumption by 11-40\% and increasing in extraction of precious minerals (Dzhezkazganskaia, Balkhashskaia, Almalykskaia, Gaiskaia, Akchatauskaia plants) is used [7-10].

Increase in efficiency of flotation of titanium-zirconic sands, gold from ledge ores, coal, cinnabar, antimonite and selection of lead-pyritic and copper-pyritic concentrates under the impact of ultrasound on heterogenic systems of flotation pulps was noted [11-14]. Insonation of bulk sulphide flotations pulps within 5-20 minutes abruptly decreases flotation response of galena, bornite pyrite, arsenopyrite with retention of flotation of sphalerite, chalcopyrite and pyrrhotite. The difference of kinetics and desorption of collectors from mineral surfaces enables increasing coefficient of minerals selectivity process [13].

Based upon research findings received during the beneficiation of carbonate-fluorite raw materials, ultrasonic treatment of water coming for dilution of froths of cleanings allows reducing the quantity of cleaning operations by means of the growth of selectivity of separation process and increasing fluorite extraction by 7-8 \% [15-16].

Based upon theoretical research in this field, main factors influencing flotation process activation were outlined: processes of surface cleaning, cracks opening, splices destruction, structure rupture with caving, microflaws, cavity processes going on in liquid and reinforcing on the boundary of liquid and solid phases, alternation of chemical and phase composition in near-surface layer [17].

Stimulation of beneficiation is one of directions in increasing feasibility of mineral raw materials flotation processing patterns, it is especially important while precious minerals content is decreasing in head ore.

For plant finishing field mining, the increase in feasibility of mining is connected with the stimulation of flotation processes by means of ore feed, reagent schemes, process water treatment.

Goal of research performed: determine main promising trends of ultrasonic treatment application with Vostok-2 field tungsten ores beneficiation.

Results of chalcopyrite beneficiation ability in sulphide cycle in case of ultrasound impact on liquid phase of flotation, process (circulating) water and reagents are represented in Table 1

The best result of chalcopyrite flotation response increase has been obtained with circulating water treated with ultrasound.

It was noted in the previous research that ultrasound impact changes physical and chemical properties of water: $\mathrm{pH}$, electrical conductivity, reduction-oxidation potential, xanthate ions, cyanic compounds and other flotation agents break up, sulphide reagents electrolytic potentials change. With the intensity of acoustic vibrations of $10 \mathrm{~W} / \mathrm{cm}^{2}$ and frequency of $22 \mathrm{kHz}$ and the duration of water treatment of $0.5-10$ minutes, the extraction of chalcopyrite increases by $12 \%$ [18].

The dependence of $\mathrm{pH}$ change and temperature on time of ultrasonic treatment of tap and process water is given in fig. 2 .

In our experiments, insonation of circulating water containing $8.7 \mathrm{~g} / 1$ of suspended solids, with volume of $250 \mathrm{ml}$ with the intensity of acoustic vibrations of $1.0 \mathrm{~W} / \mathrm{cm}^{2}$ and frequency of $22 \mathrm{kHz}$ within 5 minutes (see fig. 2) led to the reduction of water $\mathrm{pH}$ by 0.19 (from 8.19 to 8.0 ) with insignificant increase in temperature from $20{ }^{\circ} \mathrm{C}$ to $26{ }^{\circ} \mathrm{C}$. The clarification of insonated water for a day amounted to $28 \%$, by initial sample $-36 \%$. Ultrasonic treatment leads to the enhancement of colloidal solution disability. With the reduction of insonated water volume down to $100 \mathrm{ml}$, as a consequence of the growth of intensity of impact on water, the reduction of $\mathrm{pH}$ by 0.59 and the degree of clarification to $19 \%$ was obtained. 
Table 1. Results of chalcopyrite beneficiation in sulphide cycle using ultrasonic treatment of water medium and collectors

\begin{tabular}{|c|c|c|c|c|c|c|c|c|}
\hline \multirow{3}{*}{$\begin{array}{c}\text { Item of } \\
\text { insonation }\end{array}$} & \multicolumn{3}{|c|}{ Sulphide concentrate } & \multicolumn{3}{|c|}{ Sulphide middlings } & \multirow{2}{*}{\multicolumn{2}{|c|}{$\begin{array}{c}\text { Sulphide } \\
\text { flotation tailings } \\
\text { Copper, } \% \\
\end{array}$}} \\
\hline & \multirow[b]{2}{*}{$\begin{array}{c}\text { Outpu } \\
\mathbf{t} \\
\%\end{array}$} & \multicolumn{2}{|c|}{ Copper, \% } & \multirow[b]{2}{*}{$\begin{array}{c}\text { Outpu } \\
\text { t } \\
\%\end{array}$} & \multicolumn{2}{|c|}{ Copper, \% } & & \\
\hline & & $\begin{array}{l}\text { Con } \\
\text { tent }\end{array}$ & $\begin{array}{c}\text { Extr } \\
\text { actio } \\
\text { n }\end{array}$ & & $\begin{array}{c}\text { Conte } \\
\text { nt }\end{array}$ & $\begin{array}{c}\text { Extr } \\
\text { actio } \\
n\end{array}$ & $\begin{array}{c}\text { Cont } \\
\text { ent }\end{array}$ & $\begin{array}{c}\text { Extracti } \\
\text { on }\end{array}$ \\
\hline \multicolumn{9}{|c|}{ Without ultrasonic treatment } \\
\hline $\mathrm{H}_{2} \mathrm{O}$ tap water. & 14.16 & 1.32 & 81.15 & 8.27 & 0.30 & 10.77 & 0.024 & 8.08 \\
\hline $\begin{array}{l}\mathrm{H}_{2} \mathrm{O} \text { circulating } \\
\text { water }\end{array}$ & 13.19 & 1.38 & 79.43 & 7.16 & 0.36 & 11.21 & 0.027 & 9.36 \\
\hline \multicolumn{9}{|c|}{ Ultrasonic-treated (volume $250 \mathrm{ml}$, time of insonation -5 minutes) } \\
\hline $\mathrm{H}_{2} \mathrm{O}$ tap water. & 13.29 & 1.38 & 79.76 & 9.78 & 0.28 & 11.89 & 0.025 & 8.35 \\
\hline $\begin{array}{c}\mathrm{H}_{2} \mathrm{O} \text { circulating } \\
\text { water. }\end{array}$ & 12.82 & 1.48 & 80.84 & 5.65 & 0.42 & 10.31 & 0.025 & 8.85 \\
\hline Pulp of flotations & 14.47 & 1.31 & 82.05 & 5.84 & 0.30 & 7.59 & 0.030 & 10.36 \\
\hline IMA-I413p & 13.16 & 1.44 & 82.13 & 4.97 & 0.50 & 10.78 & 0.020 & 7.09 \\
\hline $\begin{array}{c}\text { IMA- } \\
\text { I413p+potassium } \\
\text { butyl xanthate }\end{array}$ & 14.09 & 1.33 & 81.66 & 4.25 & 0.59 & 10.86 & 0.021 & 7.48 \\
\hline & & & 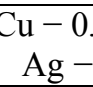 & . & 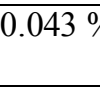 & 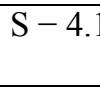 & & $-1.0 \mathrm{~g}$ \\
\hline
\end{tabular}

$a$

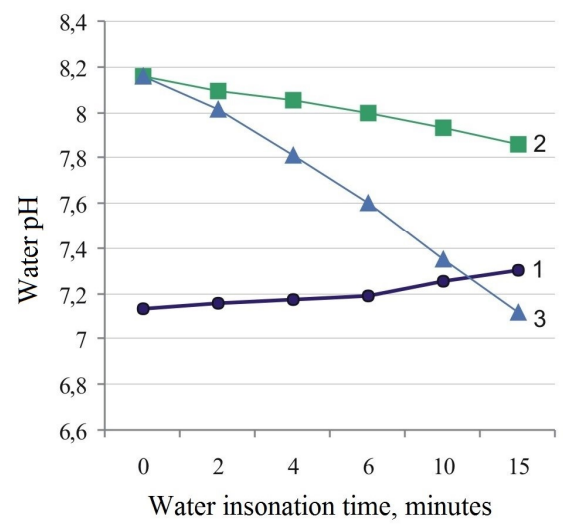

$\mathrm{b}$

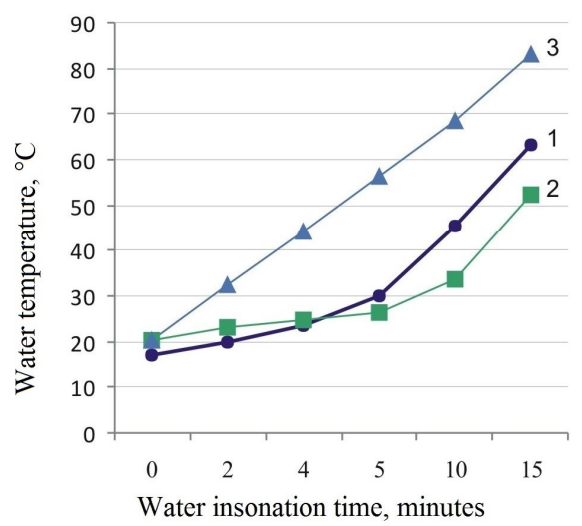

Fig. 2. The dependence of $\mathrm{pH}$ (a) and temperature of water (b) on time of ultrasonic treatment: 1 - tap water $(250 \mathrm{ml}), 2,3$ - circulating water $(250$ and $100 \mathrm{ml})$

In case of using ultrasonic treated circulating water $(\mathrm{V}-250 \mathrm{ml}, \mathrm{t}-5$ minutes $)$ in the process of flotation, the increase in extraction of chalcopyrite into sulphide concentrate by $1.41 \%$ was achieved. The drop of the activity of arsenopyrite flotation in bulk cycle by 4.6 $\%$, pyrrhotite $-3.1 \%$, was noted.

Saleable concentrate was obtained in copper selection with the increment of extraction by $1.36 \%$, at that the reduction of losses with copper tailings of selection $-5.96 \%$ which should lead to greater increment of copper extraction in experiments of locked cycle tests.

Insonation of aeroflot IMA-I413p let to reduce losses of chalcopyrite with tailings of bulk cycle by $0.98 \%$, with treatment of the mixture of aeroflot reagents and butyl xanthate losses reduced by $0.51 \%$ which proves data of partial breaking of xanthate. 
Data on ultrasound impact on scheelite flotation are given in Table 2.

Table 2. Values for beneficiation of scheelite from ore using acoustic vibrations

\begin{tabular}{|c|c|c|c|c|c|c|c|c|}
\hline \multirow{3}{*}{$\begin{array}{l}\text { Item of } \\
\text { treatme } \\
\text { nt }\end{array}$} & \multicolumn{3}{|c|}{$\begin{array}{l}\mathrm{WO}_{3} \text { concentrate } \\
\text { of basic cycle }\end{array}$} & \multicolumn{3}{|c|}{ Steaming feed } & \multirow{2}{*}{\multicolumn{2}{|c|}{$\begin{array}{l}\mathrm{WO}_{3} \\
\text { tailings }\end{array}$}} \\
\hline & \multirow{2}{*}{$\begin{array}{l}\text { Outp } \\
\text { ut, } \%\end{array}$} & \multicolumn{2}{|c|}{$\mathrm{WO}_{3}, \%$} & \multirow{2}{*}{$\begin{array}{l}\text { Outp } \\
\text { ut, } \\
\%\end{array}$} & \multicolumn{2}{|c|}{$\mathrm{WO}_{3}, \%$} & & \\
\hline & & $\begin{array}{l}\text { Conte } \\
\text { nt }\end{array}$ & $\begin{array}{l}\text { Extracti } \\
\text { on }\end{array}$ & & $\begin{array}{l}\text { Conte } \\
\text { nt }\end{array}$ & $\begin{array}{l}\text { Extracti } \\
\text { on }\end{array}$ & $\begin{array}{l}\text { Conte } \\
\text { nt }\end{array}$ & $\begin{array}{l}\text { Extracti } \\
\text { on }\end{array}$ \\
\hline \multicolumn{9}{|c|}{ Without ultrasonic treatment } \\
\hline $\begin{array}{l}\mathrm{H}_{2} \mathrm{O} \text { tap } \\
\text { water. }\end{array}$ & 19.59 & 3.78 & 94.85 & 17.95 & 4.05 & 93.17 & 0.050 & 5.15 \\
\hline $\begin{array}{l}\mathrm{H}_{2} \mathrm{O} \\
\text { circulati } \\
\text { ng } \\
\text { water }\end{array}$ & 27.61 & 2.62 & 92.70 & 16.03 & 4.35 & 87.88 & 0.08 & 7.30 \\
\hline \multicolumn{9}{|c|}{ Ultrasonic-treated } \\
\hline $\begin{array}{l}\mathrm{H}_{2} \mathrm{O} \text { tap } \\
\text { water. }\end{array}$ & 21.85 & 3.30 & 95.01 & 19.90 & 3.63 & 92.61 & 0.050 & 5.00 \\
\hline $\begin{array}{l}\mathrm{H}_{2} \mathrm{O} \\
\text { circulati } \\
\text { ng } \\
\text { water }\end{array}$ & 22.35 & 3.28 & 95.16 & 15.45 & 4.65 & 93.37 & 0.048 & 4.84 \\
\hline $\begin{array}{l}\text { Pulp of } \\
\text { flotatio } \\
\text { ns }\end{array}$ & 20.23 & 3.65 & 95.86 & 10.70 & 5.32 & 73.85 & 0.040 & 4.14 \\
\hline $\begin{array}{l}\text { Sodium } \\
\text { oleate }\end{array}$ & 18.57 & 3.93 & 94.70 & 10.45 & 5.85 & 79.58 & 0.050 & 5.30 \\
\hline
\end{tabular}

Ultrasonic treatment of circulating water led to the stimulation as well as for scheelite flotation. Significant increment of scheelite extraction of $2.46 \%$ was obtained in bulk cycle. Increase in extraction is connected with the reduction of tungsten trioxide content in tailings of scheelite flotation from $0.08 \%$ to $0.048 \%$ with the reduction of rough concentrate output by $5.3 \%$.

Circulating water insonation let to obtain values of precious minerals extraction close to values on tap water.

Process water ultrasonic treatment is especially important for ore-processing plants during autumn-winter work period when substantial water quality reduction by suspended solids occurs. At Primorskaia ore-processing plant, concentrate is extracted from skarn scheelite-sulphide ore with $\mathrm{WO}_{3}$ content of $0.56 \%$ in summer (suspended solids in circulating water - 2.9-1.0 g/l) with the extraction of scheelite of $86.9 \%$, with concentrate quality of $53 \% \mathrm{WO}_{3}$, with the increase of suspended solids up to $6.0 \mathrm{~g} / 1$ accordingly 82.6 $\%$ and $52.8 \%$ (losses $-4.3 \%$ ). With the increase of suspended solids in water up to $12 \mathrm{~g} / \mathrm{l}$ the losses grow up to $6.5 \%$.

\section{Conclusions}

As a result of performed testing of skarn scheelite-sulphide ore from Vostok-2 deposit for beneficiation ability in case of ultrasonic treatment impact (working frequency $22 \mathrm{kHz}$, absorbed acoustic power average for radiator Pak $=46 \mathrm{~W}$, sound intensity average $\mathrm{I}_{\mathrm{us}}=1$ $\mathrm{W} / \mathrm{cm}^{2}$ ) it has been established that the greatest increment of precious minerals extraction is obtained with circulating water insonation. Increment of extraction of chalcopyrite into copper concentrate amounted to $1.4 \%$ and scheelite into bulk rough concentrate $-2.5 \%$. 
Best results for collectors ultrasonic treatment have been obtained for dialkyldithiophosphates (IMA-I413p), increase in extraction of chalcopyrite into bulk sulphide concentrate amounts to $0.98 \%$.

\section{References}

1. V.I. Revnivtsev Feldspars and quartz beneficiation. M: Nedra 250 (1970)

2. I.M. Babakov. Theory of oscillations. M., (1966)

3. E. Kikuchi. Ultrasonic sensors. M., (1968)

4. V.A. Glembotskii, M.A. Sokolov, I.A. Iakubovich and others Ultrasound in mineral deposits beneficiation. Almaty (1972)

5. N.M. Lebedev, G.I. Zhirnova, G.V. Sedelnikova and others Technology and equipment for beneficiation ultrasonic stimulation. Source book for IX Congress of CIS countries beneficiating companies, 1, 338-34, (February 26-28, 2013).

6 V.A. Chanturiiaa. Electrochemestry of sulphides. Theory and practice of flotation. M.: Ore and metals, 272 (2008).

7. Iu.P. Eremin, G.A. Denisov, M.D. Shtern and others Concerning future solutions on using vibration and acoustic oscillations on flotation processes. Ore beneficiation, 3,2428 (1981).

8. G.I. Eskin, I.I. Gurev, Iu.F. Soluianov. The impact of ultrasonic treatment of melting on properties of zink ingots and plates. Non-ferrous metals, 5, 69-71 (1981)

9. Z. Bonderek, et. al. Prafinaejes ultradźwięki odlewniczego stopu alum. AK 9. Przeglad Odlewnictwa, 7, 229-232 (1981).

10. B.A. Agranat. Research of acoustic cavitation erosive activity in organic solvents. Acoustic magazine, 29, issue 5, 577-579 (1983).

11. A.A. Abramov. The technology of processing and beneficiation of non-ferrous metals ores. M., Publishing house Moscow State Mining University, 1, 575,(2005).

12. V.A. Tsarkov, V.V. Dobroskokin. Current trends of the development of gold extraction from ledge ores. Mining magazine, 5, 81-82 (2000).

13. N. Ghaffari. Scavenging Flotation Tailings using a Continuous Centrifugal Gravity Concentrator. The University of British Columbia, Vancouver, Augus. 167 (2004)

14. J.R. Walklate, P.J. Fourie, A history of gravity separation of Richards Bay Minerals. The Journal of the Southern African Institute of Mining and Metallurgy. 106, 741-748 (November 2006).

15. L.A. Kienko, L.A. Samatova, O.V. Voronova. The impact of pulp ultrasonic treatment on flotation selectivity in carbonate-fluorite ores beneficiation. Promlems of comprehensive development of geological resources. Materials of V National scientific conference in Khabarovsk city, Mining information-analytical bulletin, Instalment 4, 172179, (October 2-4, 2013).

16. L.A. Kienko, O.V. Voronova, Zh.A. Shagina. Increasing effectiveness of fluorite flotation based on pulp ultrasonic treatment application. Problems of comprehensive development of geological resources: Materials of VI National scientific conference with the participation of foreign scientists. Khabarovsk, 21, 233-241 (05-07 October 2016).

17. N.M. Lebedev, O.V. Voronin ("Aleksandra-Plius", LLC), S.S. Lozhnikov and others The use of ultrasound for beneficiation stimulation. ("GVINTSVETMET" Federal State Unitary Enterprise) Materials of V Congress of CIS countries beneficiating companies, 3, 225, (March 23-25, 2005).

18. N.K. Algenbranstova, A.V. Makshanin. Flocculation as a method of gold extraction from tailing resources. Journal of Siberian Federal University. Engineering Technologies.3, 283-295 (2011). 